\title{
Don't Forget Non-code Statutes
}

\author{
by Benjamin J. Keele
}

When I first learned about legal research, case law research seemed so confusing and messy. In any given reporter volume, I could find a financial crimes case followed by a contract dispute, followed by a challenge to an estate. I had to rely on full-text searches or a digest to find cases on a given topic.

Statutes, on the other hand, seemed neat and organized. Crimes were in one title of the code, and there was a helpful table of contents that showed all the topics in a title, article, or chapter. Many statutes even followed a pattern: policy statements, definitions, general rules, and then exceptions. These first impressions led me to believe that, compared to researching judicial opinions, researching statutes was much simpler and I could be much more confident that I was finding all the relevant documents for my topic. Like many things in law, statutory research is more nuanced and challenging than it seems at first glance.

When I look at the massive sets of books in a current federal or state statutory code, I'm surprised by how many laws we have. What is even more surprising is that a code doesn't contain all the statutes of a jurisdiction. The session laws constitute the complete set of laws enacted in a jurisdiction. Session laws aren't easy to use, so compilers codify them into topical arrangements of laws. But these codes often include only laws of general and permanent effect. Laws that have expiration dates or apply to a specific situation, while in full effect, are often omitted from codes. When you look only in the code, it is difficult to be certain you've found all the relevant, effective statutes. Examples of non-code laws include riders to appropriations bills, ${ }^{1}$ transitional relief from changes to tax laws, ${ }^{2}$ and qualifications on the effect of an in-code provision. ${ }^{3}$ The articles cited in the endnotes have a fair number of specific examples.
A brief glance at the 2011 Acts of the General Assembly reveals several enacted laws that probably won't appear in the Virginia Code. Chapter 3 revised the election calendar for the 2011 primary and general elections. ${ }^{4}$ The law was effective for less than a year, expiring on January 1, 2012, so it probably never appeared in a code. Chapter 11, the Commonwealth of Virginia Higher Educational Institutions Bond Act of 2011, authorized financing for construction at some universities. ${ }^{5}$ The effect of the law isn't permanent or general, so it probably won't ever appear in the Virginia Code, either. Even setting aside the biennial budget bills, more instances of Virginia non-code laws could likely be easily found.

Clearly it is risky to rely exclusively on codes for statutory research. What can be done to avoid missing relevant provisions that aren't codified? Check annotations or compiler's notes for references to non-code language that affects codified provisions. I've often found mentions of limitations on scope or effective dates in these notes. Some compilers may even produce tools to help find non-code laws. ${ }^{6}$ Examine every session law listed in a code section's history notes as enacting or amending the section. This research may take some time, but it is likely to catch non-code sections that affect the code section. The main risks of this method are errors in the history notes or a complete recodification of a title that obliterates the notes.

A relevant section in a code provides the terms legislators use to describe an issue. Since non-code laws are often left out of the code because they are temporary, it is worthwhile to use those key terms and search the session laws of the past five years to see if any provisions were enacted on that issue that weren't codified. Be especially careful about areas and types of law that change fre- quently. If you know that the title of a code on civil procedure was recently revised, non-code provisions may have also been enacted to deal with the transition to the new title. State activities that are regularly authorized and given appropriations may have non-code riders. If a rider is enacted consistently, it can become just as established as a code provision. At the federal level, the Hyde Amendment limiting funding for abortions ${ }^{7}$ and the prohibition on transferring detainees in the Guantanamo Bay prison to U.S. soil ${ }^{8}$ are examples of established appropriations riders. In these circumstances, searching the session laws will be the primary way of finding relevant provisions. Current secondary sources on the topic may also mention provisions that don't appear in the code.

Statutory codes are valuable tools, but they don't contain a complete set of all enacted legislation. To be more certain of finding all relevant laws, check compiler's notes and session laws for non-code provisions, especially when statutes have been recently revised or are regularly renewed.

Non-code Statutes continued on page 57

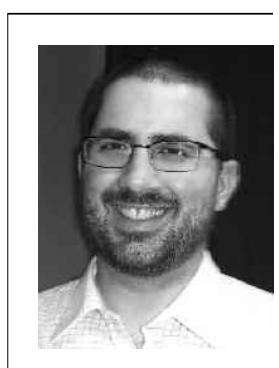

Benjamin J. Keele is a research and instructional services librarian in the Ruth Lilly Law Library, Indiana University Robert H. McKinney School of Law. He was previously a reference librarian in the Wolf Law Library, William \& Mary Law School. 


\section{Non-code Statutes continued on page 49}

\section{Endnotes:}

1 Will Tress, Lost Laws: What We Can't Find in the U.S. Code, 40 GOLDEN GaTe U. L. REV. 129, 139 (2010).

2 Christopher H. Hanna, The Magic in the Tax Legislative Process, 59 SMU L. REV. 649, 658 (2006).

3 Marcia J. Oddi, Can You Rely on the Indiana Code? Part I - Noncode Sections, Res Gestae, May 2008, at 20, 23.

$42011 \mathrm{Va}$. Acts 2.

52011 Va. Acts 14.

6 Indiana, for one, has lists of non-code acts at http://www.in.gov/legislative/ic /noncode/.

7 Most recently enacted in Consolidated and Further Continuing Appropriations Act, 2013, Sec. 202, Pub. L. 113-6, 127 Stat. 198, 257.

8 Most recently enacted in Consolidated and Further Continuing Appropriations Act, 2013, Sec. 511, Pub. L. 113-6, 127 Stat. 198, 411. 